\title{
ANALISIS ARTIKEL METODE MOTIVASI DAN FUNGSI MOTIVASI BELAJAR SISWA
}

\section{ARTICLE ANALYSIS OF MOTIVATION METHODS AND STUDENT LEARNING MOTIVATION FUNCTIONS}

\begin{tabular}{l} 
Neni Fitriana \\
Harahap $^{1}$ \\
Universitas \\
Labuhanbatu, \\
Indonesia $^{1}$ \\
email: \\
harahapnenifitriana@g \\
mail.com \\
Dewi Anjani ${ }^{2}$ \\
Universitas \\
Labuhanbatu, \\
Indonesia ${ }^{2}$ \\
email: \\
dewianzani4895@gmail \\
.com \\
Nabsiah Sabrina \\
Universitas \\
Labuhanbatu, \\
Indonesia ${ }^{3}$ \\
email: \\
nabsiahsabrina4@gmail \\
.com \\
IJI Publication \\
p-ISSN: 2774-1907 \\
e-ISSN: 2774-1915 \\
Vol. 1, No. 3, pp. 198- \\
203, Juli 2021 \\
in Unit Publikasi Ilmiah \\
intektual Madani \\
PENdonesia \\
\hline PENAHULAN
\end{tabular}

Untuk mendukung keberhasilan dalam dunia pendidikan, pemerintah tentu memberikan perhatian khusus terhadap komponen-komponen yang berperan dalam pendidikan itu sendiri. Salah satunya komponen pendukung pendidikan yang sering diperbincangkan adalah pendidikan. Dalam hal kualitas pendidikan sangat berpengaruh pada pembentukan karakter dari peserta didiknya dimasa mendatang. Pendidikan memiliki peran dalam dunia pendidikan. Tujuan pendidikan sering dirumuskan untuk menyiapkan generasi muda menjadi orang dewasa anggota masyarakat yang mandiri dan produktif dimana fungsi sekolah erat hubungannya dengan masyarakat.

Keberhasilan pencapaian tujuan pendidikan disekolah dipengaruhi oleh beberapa faktor diantaranya adalah motivasi belajar siswa. Karena motivasi merupakan dorongan yang diberikan kepada individu (siswa) untuk melaksanakan pembelajaran.

Hamalik (Djamarah, 2011), menyebutkan bahwa motivasi adalah suatu perubahan energi di dalam pribadi seseorang yang ditandai dengan timbulknya afektif (perasaan) dan reaksi untuk mencapai tujuan. Perubahan energi dalam diri seseorang itu berbentuk aktivitas nyata berupa kegiatan fisik, karena seseorang memiliki tujuan 
tertentu dari aktivitasnya, maka seseorang memiliki motivasi yang kuat untuk mencapainya dengan segala upaya yang dapat dia lakukan untuk mencapainya.

Motivasi merupakan faktor psikologis penting dalam proses pembelajaran. Motivasi di bangkitkan melalui situasi stimulus bersama ingatan untuk dapat mempengaruhi siswa sedemikian rupa sesuai hukum-hukum mekanik sehingga berfungsi dalam mengarahkan, mengaktifkan dan meningkatkan aktivitas siswa dalam proses pembelajaran (Shihusa dan Keraro,2009; Solomon, 1986; Tasiwan, 2013). Tingkat motivasi siswa dalam pembelajaran mempengaruhi perkembangan belajar dan hasil belajar siswa. Hasil penelitian Tella (2007) melaporkan bahwa anak-anak yang memiliki motivasi tinggi dalam belajar, memiliki tingkat perkembangan belajar dan hasil belajar yang baik. Didukung dengan hasil penelitian Nelson (2000) mengungkapkan bahwa ada hubungan positif antara motivasi, perkembangan kognitif, dan perubahan konseptual.

Hamalik (2012), menyatakan bahwa pembelajaran merupakan kombinasi yang tersusun meliputi unsur-unsur manusiawi, material, fasilitas, perlengkapan, dan prosedur yang saling mempengaruhi mencapai tujuan pembelajaran.

Motivasi siswa dalam pembelajaran dapat ditingkatkan melalui berbagai model dan pendekatan. Maka dari itu tujuan penelitian ini adalah untuk menganalisis artikel dengan metode motivasi dan fungsi motivasi belajar siswa.

\section{METODE ANALISIS}

Untuk mengatasi masalah penelitian, peneliti melakukan studi literatur dengan menggunakan prosedur disarankan oleh Cooper (1988) untuk mensintesis literatur. Prosedur sistematis ini membantu untuk (a) merumuskan masalah, (b) mengumpulkan data,(c) mengevaluasi kelayakan data, (d) menganalisis dan menafsirkan data yang relevan, dan (e) mengatur dan menyajikan hasilnya. Kemudian hasilnya dibandingkan dengan arus masalah di lembaga pendidikan tinggi yang besar.

Merumuskan masalah. Masalahnya adalah merangkul motivasi belajar siswa yang mengidentifikasi dari metode dan fungsi motivasi belajar siswa. Kedua komponen kunci ini perlu klarifikasi lebih lanjut untuk pendidikan pemangku kepentingan untuk membantu mereka menerapkan analitik pembelajaran secara efektif di pendidikan. Untuk membantu memecahkan masalah, pertanyaan-pertanyaan berikut memandu tinjauan ini: 1) Apa aja metode untuk meningkatkan motivasi belajar siswa?. 2) Apa saja fungsi motivasi belajar siswa?

Mengidentifikasi dan menjelaskan metode dan fungsi motivasi belajar siswa lebih lanjut dapat membantu pendidik dalam pendidikan untuk meningkatkan motivasi belajar siswa.

Pengumpulan data. Tujuan pengumpulan data adalah untuk menemukan studi empiris termasuk: kuantitatif, kualitatif, metode campuran, dan tinjauan literatur yang diterbitkan dalam jurnal peer-review sejak 2000 untuk mengidentifikasi metode dan fungsi motivasi belajar siswa dalam pendidikan. Kata kunci yang digunakan termasuk analisis dan metode motivasi pembelajaran, analisis dan fungsi motivasi pembelajaran.Basis data yang digunakan untuk penelitian literatur termasuk Science and Technology Index (Sinta).

Evaluasi dan analisis data. Berdasarkan prosedur yang dijelaskan, 27 artikel ditemukan. Dari ini, 7 artikel berfokus pada isu-isu yang berkaitan dengan metode analisis motivasi belajar siswa, dan 1 artikel pada fungsi motivasi belajar siswa, artikel yang tersisa dikeluarkan dari ulasan ini karena tidak dapat digunakan untuk menjawab dua pertanyaan utama penelitian. Hanya artikel yang berhubungan langsung dengan metode 
dan fungsi serta membantu menjawab dua pertanyaan penelitian dimasukkan dalam tinjauan ini. Metode yang dijelaskan oleh Cooper (1988) tepat untuk memandu tinjauan sistematis literatur.P ara peneliti menghabiskan literatur menggunakan prosedur ,kata kunci, dan database yang dijelaskan di atas. Selanjutnya, peneliti membatasi pencarian literatur pada kata kunci dan database yang ditentukan. Oleh karena itu, literatur ini mungkin tidak menyertakan sumber yang tidak tersedia melalui kriteria dan database yang dicari.

\section{PEMBAHASAN}

Metode Meningkatkan Motivasi Belajar Siswa. Motivasi merupakan faktor psikologis penting dalam proses pembelajaran. Motivasi belajar sangatlah berperan penting dalam kesuksesan belajar sebab tanpa adanya motivasi yang melekat dibenak akan sulit mewujudkan segala tindakan ke arah lebih baik. Menurut Clayton Alderfer (Nashar, 2004) "motivasi belajar adalah kecenderungan siswa dalam melakukan kegiatan belajar yang didorong oleh hasrat untuk mencapai prestasi atau hasil belajar sebaik mungkin". Hasil penelitian Tella (2007) melaporkan bahwa anak-anak yang memiliki motivasi tinggi dalam belajar, memiliki tingkat perkembangan belajar dan hasil belajar yang baik. Motivasi siswa dalam pembelajaran dapat ditingkatkan melalui berbagai model dan pendekatan.

Dalam pembelajaran proyek, motivasi siswa muncul melalui pengalaman siswa dalam lingkungan belajar yang kaya akan sumber - sumber belajar, kerjasama dan bermakna guna serta konstruksi tugas-tugas dan pekerjaan yang otentik (Keraro, et. al., 2007; Vrasidas, 2000). 1) Keterampilan membuka pelajaran adalah kemampuan guru dalam mengawali pembelajaran dengan melakukan: a). Apersepsi dengan menanyakan materi pelajaran yang lalu. b) Menimbulkan motivasi menumbuhkan rasa ingin tahu atau mengemukakan ide yang bertentangan. c) Memberi acuan dengan mengemukakan tujuan pembelajaran dan batas-batas tugas atau langkah-langkah pembelajaran yang akan dilakukan. 2) Motivasi belajar siswa adalah dorongan belajar pada diri siswa yang meliputi tekun menghadapi tugas, ulet menghadapi kesulitan, menunjukkan minat terhadap bermacam-macam masalah belajar, lebih senang bekerja mandiri, tidak cepat bosan dengan tugas-tugas rutin,dapat mempertahankan pendapatnya, tidak mudah melepaskan apa yang diyakini, senang mencari dan memecahkan masalah.

Menurut Astuty (2011) model pembelajaran example non example menempatkan siswa ke dalam kelompokkelompok kecil yang heterogen,dimana pembelajaran disajikan dalam bentuk gambar, diagram atau tabel yang sesuai dengan materi bahan ajar dan kompetensi dasar. Selain itu salah satu cara penyampaian materi yang dapat menjembatani antara konsep yang abstrak dan real.

Menurut Usman (2010) motivasi yang berasal dari dalam diri siswa (intrinsik) timbul sebagai akibat dari dalam individu tersebut karena adanya ajakan,suruhan,atau paksaan dari orang lain sehingga dengan kondisi demikian akhirnya ia mau melakukan sesuatu atau belajar. Menurut Djamarah (2002) motivasi yang berasal dari luar (ekstrinsik) ialah motif-motif yang aktif dan berfungsi karena adanya rangsangan dari luar, seperti adanya kompetisi/persaingan.

Pendidikan harus berusaha

menimbulkan motif intrinsik dengan menumbuhkan dan mengembangkan minat peserta didik terhadap jenis bidang studi yang relevan. Sebagai contoh, memberitahukan sasaran yang hendak dicapai dalam bentuk tujuan instruksional pada saat pembelajaran akan dimulai yang menimbulkan motif keberhasilan mencapai sasaran.Selanjutnya untuk menumbuhkan motif ekstrinsik,dalam 
tinjauan Uno (2008), ada beberapa persiapan yang dapat dilakukan oleh seorang guru, yaitu: a) Pendidik memerlukan anak didiknya sebagai manusia yang berpribadi, menghargai pendapatnya, pikirannya, perasaannya, maupun keyakinannya. b) Pendidikan menggunakan berbagai metode dalam melaksanakan kegiatan pendidikannya. c) Pendidik senantiasa memberikan bimbingan dan pengarahan kepada anak didiknya dan membantu apabila mengalami kesulitan,baik yang bersifat pribadi maupun akademik. d) Pendidik harus mempunyai pengetahuan yang luas dan penguasaan bidang studi atau materi yang diajarkan kepada peserta didiknya. e) Pendidik harus mempunyai rasa cinta dan sifat pengabdian kepada profesinya sebagai pendidik. Semua ciri tersebut harus dimiliki oleh pendidik dalam upaya memberikan motivasi kepada peserta didiknya dan mengabdi kepada profesinya sebagai pendidik.

Salah satu contoh motivasi yang berasal dari luar diri siswa (ekstrinsik) adalah orang tua,dimana orang tua merupakan orang yang pertama kali dikenal dan dekat dengan anak, keberadaan siswa antara di sekolah dengan di rumah tentunya lebih banyak di rumah,maka dari itu peran orang tua sebagai orang yang dekat dengan siswa dinilai sangat penting terutama dalam memotivasi belajar siswa. Diantara peran orang tua dalam memotivasi belajar siswa adalah sebagai berikut: 1) Dengan mengontrol waktu belajar dan cara belajar anak. 2) Memantau perkembangan kemampuan akademik anak. Orang tua diminta untuk memeriksa nilai-nilai ulangan dan tugas anak mereka. 3) Memantau perkembangan kepribadian yang mencakup sikap, moral dan tingkah laku anak-anak.Hal ini dapat dilakukan orang tua dengan berkomunikasi dengan wali kelas untuk mengetahui perkembangan anak di sekolah. 4) Memantau efektifitas jam belajar di sekolah. Orang tua dapat menanyakan aktifitas yang dilakukan anak mereka selama berada di sekolah.

Terkait dengan peran orang tua dalam memotivasi belajar siswa, maka ada beberapa cara yang dapat dilakukan oleh orang tua untuk meningkatkan motivasi belajar siswa, diantaranya sebagai berikut: a) Menciptakan iklim rumah yang mendukung anak untuk belajar orang tua dapat menyediakan berbagai perlengkapan maupun permainan yang dapat mendukung anak untuk belajar, misalnya: komputer, buku-buku, puzzle, dan sebagainya. b) Menyediakan waktu yang cukup untuk terlibat dalam kegiatan belajar anak. Selain menciptakan iklim rumah yang dapat mendukung anak untuk belajar, interaksi orang tua dengan anak ternyata juga dapat meningkatkan motivasi belajar anak. Hal ini dapat dilakukan dengan menemani anak belajar, menunjukkan perhatian terhadap kegiatan belajar anak, memberikan bantuan ketika anak menghadapi kesulitan,dan sebagainya. Sebagai partner anak dalam belajar, orangtua sebaiknya menunjukkan sikap yang hangat dan positif terhadap anak,misalnya dengan tidak memarahi anak ketika anak tidak dapat mengerjakan PR-nya dengan baik. c) Memberikan penghargaan atau respon positif terhadap setiap prestasi anak. Hal ini dapat dilakukan dengan berbagai cara,misalnya: dengan memberikan hadiah atau pujian. Dengan demikian, anak merasa dihargai dan lebih termotivasi untuk melakukan sesuatu.

Tercapainya berbagai kebutuhankebutuhan siswa dapat meningkatkan motivasi siswa dalam kegiatan belajarnya, antara lain: 1) Kebutuhan-kebutuhan belajar siswa di rumah difasilitasi oleh orangtua atau anggota keluarga lain. Pemenuhan kebutuhan fisiologis siswa di sekolah terlihat dengan adanya kantin sekolah yang memadai,ruang kelas yang memadai, dan waktu istirahat yang cukup. Pemenuhan kebutuhan fisiologis siswa merupakan hal yang paling esensial dalam kehidupan siswa. Hal itu sebagaimana 
pendapat Schunk, et. al. (2012) bahwa perwujudan paling nyata dari kebutuhan fisiologis adalah kebutuhan-kebutuhan pokok manusia. Kebutuhan ini merupakan kebutuhan yang paling dasar, seperti cukup makanan, udara, air untuk bertahan hidup. Jadi, berdasarkan keseluruhan pembahasan mengenai kebutuhan fisiologis siswa di rumah dan sekolah dapat dibangun proposisi nutrisi makanan yang baik, kebutuhan finansial yang memadai,waktu istrahat yang cukup, kantin sekolah yang memadai menjadi faktor yang dapat meningkatkan motivasi belajar siswa. 2) Kebutuhan rasa aman siswa di rumah dan sekolah dapat dibangun proposisi bantuan belajar, penyediaan tempat belajar yang nyaman, pengendalian sikap buruk siswa di kelas dan sikap baik guru dalam mengajar menjadi faktor yang dapat menciptakan rasa aman siswa dalam belajar sehingga motivasi belajar siswa dapat meningkat. 3) Kebutuhan rasa cinta siswa di rumah dan di sekolah dapat dibangun proposisi pendampingan belajar, jalinan komunikasi orangtua dan anak,hubungan baik antara siswa dengan guru dan temannya menjadi faktor yang dapat meningkatkan motivasi belajar siswa. 4) Kebutuhan penghargaan diri siswa di rumah dan sekolah dapat dibangun proposisi pujian, kepercayaan orangtua, hadiah, penilaian tugas siswa, dan umpan balik dari guru menjadi faktor yang dapat meningkatkan motivasi belajar siswa. 5) Kebutuhan aktualisasi diri siswa di rumah dan sekolah dapat dibangun proposisi dukungan minat,hobi, cita-cita dari orangtua dan guru serta sikap humanistik guru dalam pembelajaran menjadi faktor yang dapat meningkatkan motivasi belajar siswa.

Fungsi Motivasi Belajar Siswa. Keberhasilan proses belajar mengajar dipengaruhi oleh motivasi belajar siswa.Guru selaku pendidik perlu mendorong siswa untuk belajar dalam mencapai tujuan.Fungsi motivasi dalam proses pembelajaran yang dikemukakan oleh Wina Sanjaya (2010) yaitu: 1) Mendorong siswa untuk beraktivitas,Perilaku setiap orang disebabkan karena dorongan yang muncul dari dalam yang disebut dengan motivasi. Besar kecilnya semangat seseorang untuk bekerja sangat ditentukan oleh besar kecilnya motivasi orang tersebut. Semangat siswa dalam menyelesaikan tugas yang diberikan oleh guru tepat waktu dan ingin mendapatkan nilai yang baik karena siswa memiliki motivasi yang tinggi untuk belajar. 2) Sebagai pengarah, tingkah laku yang ditunjukkan setiap individu pada dasarnya diarahkan untuk memenuhi kebutuhannya atau untuk mencapai tujuan yang telah ditentukan. Dengan demikian Motivasi berfungsi sebagai pendorong usaha dan pencapaian prestasi. Adanya motivasi yang baik dalam belajar akan menunjukkan hasil yang baik.

Selanjutnya menurut Winarsih (2009) ada tiga fungsi motivasi yaitu: a) Mendorong manusia untuk berbuat, jadi sebagai penggerak atau motor yang melepaskan energi. Motivasi dalam hal ini merupakan motor penggerak dari setiap kegiatan yang dilakukan. b) Menentukan arah perbuatan kearah yang ingin dicapai.Dengan demikian motivasi dapat memberikan arah dan kegiatan yang harus dikerjakan sesuai dengan rumusan tujuannya. c) Menyeleksi perbuatan, yakni menentukan perbuatan-perbuatan apa yang harus dikerjakan guna mencapai tujuan, jadi adanya motivasi akan memberikan dorongan,arah dan perbuatan yang akan dilakukan dalam upaya mencapai tujuan yang telah dirumuskan sebelumnya.

Fungsi motivasi sebagai pendorong usaha dalam mencapai prestasi,karena seseorang melakukan usaha harus mendorong keinginannya, dan menentukan arah perbuatannya kearah tujuan yang hendak dicapai. Dengan demikian siswa dapat menyeleksi perbuatan untuk menentukan apa yang harus dilakukan yang berfungsi bagi tujuan yang hendak dicapainya. 


\section{KESIMPULAN}

Berdasarkan analisis yang dilakukan pada beberapa artikel yang digunakan dapat di simpulkan bahwa motivasi sangat diperlukan untuk meningkatkan minat belajar dan meningkatkan prestasi siswa. Motivasi siswa dalam pembelajaran dapat ditingkatkan melalui berbagai model dan pendekatan,serta dapat dipengaruhi juga oleh beberapa faktor.

\section{REFERENSI}

Asria Azis. (2016). Pengaruh Keterampilan Membuka Pelajaran Terhadap Motivasi Siswa Dalam Belajar Bahasa Indonesia Sekolah Dasar, 2(2), 65-73.

Dian Fitri Nur Aini, Fattah Hanurawan, Hariyono. (2016). Pengembangan Motivasi Belajar Siswa Berprestasi Anak Tenaga Kerja Indonesia (Studi Kasus Pada Siswa Sekolah Dasar Di Kabupaten Blitar), 1(9), 1875-1879.

Euis Yuniastuti. (2013). Peningkatan Keterampilan,Proses, Motivasi,Dan Hasil Belajar Biologi Dengan Strategi Pembelajaran Inkuiri Terbimbing Pada Siswa Kelas VII Pada SMP Kartika V-1 Balikpapan. Jurnal Pascasarjana Universitas Mulawarman, 14(1).

John T. Avella, Mansureh Kebritchi, Sandra G. Nunn, Therese Kanai. (2016). Learning Analytics Methods, Benefits, and Challenges in Higher Education, 20(2).

Lusi Lutfia, Yudi Prasetyo, Erwin Triawan, Muhammad Hanifan, Ripal Anwar, Wahyu Hidayat. (2019). Penerapan Model Peembelajaran Example Non Example Matematika Untuk Meningkatkan Motivasi Siswa, 1(3), 87-93.

Putri Balqis, Nasir Usman, Sakdiah Ibrahim. (2014). Kompetisi Padagogik Guru Dalam Meningkatkan Motivasi Belajar Siswa Pada SMPN 3 Ingin Jaya Kabupaten Aceh Besar, 2(1).

Sanjaya, Wina. (2010). Kurikulum dan Pembelajaran, Teori dan Praktek
Pengembangan Kurikulum KTSP, 5(2), 93196.

Selfia S. Rumbewas, Beatus M. Laka, Naftali Meokbun. (2018). Peran Orang Tua Dalam Meningkatkan Motivasi Belajar Peserta Didik di SD Negeri Saribi, 2(2), 201-212.

Tasiwan, S. E Nugroho, Hartono. (2014). Analisis Tingkat Motivasi Siswa Dalam Pembelajaran IPA Model Advance Organizer Berbasis Proyek, 3(1), 43-50.

Winarsih, Varia. (2009). Psikologi Pendidikan, 5(2), 93-196. 